be completed. Decisions have still to be made on the actual allocations of the increased funds available. The income of the Department is expected to increase by $£ 400,000$ during 1954 , the present income being approximately $£ 5$ million. Subsequent increases will bring the Department's vote to about $£ 6$ million by 1959 , an increase over the five years of about 20 per cent. Another important change in the financial arrangements for the Department is that money not spent in any given year may, subject to the necessary funds being voted by Parliament, be carried forward for use in the following year. The Department's planning of research will thus be much more flexible than hitherto, when money unspent at the end of the year has had to be surrendered. Recruitment of staff will recommence at the rate of a hundred and fifty non-industrial staff yearly, and about one-third of that number of industrial staff each year. Apart from the afore-mentioned increases, a further sum of $£ 6$ million will be available to the Department for use during the period in the erection of new buildings. The original building plan for the Mechanical 'Engineering Research Organization at East Kilbride, Glasgow, will now be completed, and the new Road Research Laboratory, necessitated by the expansion of London Airport, will now be built, as also will be the new Ship Tank at the National Physical Laboratory, Teddington. The Hydraulics Research Station, Wallingford, the Water Pollution Research Laboratory, Stevenage, and the Radio Research Station, Slough, will be completed.

\section{Parliamentary Responsibility for Atomic Energy}

IN reply to further questions in the House of Commons on November 26, the Prime Minister said that the Lord President of the Council will be responsible for' the government atomic energy establishments from January 1. The Lord President will, therefore, be responsible for ensuring that the results of research in the universities are taken into account in the work of the government atomic energy establishments. Research by the universities is, of course, carried out on their own responsibility and is mainly of a fundamental nature; but the atomic energy organization places contracts with the universities in connexion with specific research inquiries. The Prime Minister had already indicated, on November 19, that when the new system comes into operation questions relating to the responsibilities transferred from the Ministry of Supply to the Lord President of the Council would be answered by the Minister of Works. He now states that the questions of atomic energy cover so wide a field that purely technical and scientific questions only will be dealt with by the Minister of Works, while others may have to be answered by the Foreign Secretary or by himself.

\section{Fluoridation of Water}

IN a written reply to a question in the House of Commons, the Minister of Health, Mr. Iain Macleod, has announced that the Government has decided to accept the recommendations of the mission which recently visited North America to study the fluoridation of domestic water supplies as a means of controlling dental caries. The Minister, in conjunction with the Minister of Housing and Local Government, who is responsible for public water supplies in England and Wales, and the Secretary of State for Scotland, proposes to arrange for studies to be made in some selected communities of the various aspects of the fluoridation of water supplies before con- sidering whether fluoridation should be generally adopted in Britain. An approach will be made to certain local authorities to invite their co-operation in making these studies.

\section{Yorkshire Dales National Park}

THE chairman of the National Parks Commission (Sir Patrick Duff) has signed the Yorkshire Dales National Park (Designation) Order; this is the seventh National Park to be designated. The Order will be submitted in due course to the Minister of Housing and Local Government for confirmation. The area, which comprises a total of approximately 680 square miles, lies wholly within the North and West Ridings of Yorkshire. The boundary is broadly similar to that proposed in 1947 in the Hobhouse Report, though certain changes have been made, notably the addition of some 80 square miles in Sedbergh Rural District, including Dentdale and the Howgill Fells. The proposed National Park contains a wide variety of landscape which includes not only the most picturesque parts of the famous Dale country, but also some of the finest limestone scenery in Britain. From Bolton Abbey in Wharfedale, it extends northwards, through Malham with its impressive Cove, and the Gordale Scar--to Ribblesdale and the mountains-Ingleborough, Whernside and Pon-y-Ghent. Continuing northwards through upper Wharfedale with its many charming villages from West Witton to Garsdale Head, the Park extends across to Swaledale and the outskirts of Richmond, and north-west to Arkengarthdale and Bowes Moor.

\section{The Development of Canada}

During November 13-14 a conference was held in Quebec city under the title "Canada's Tomorrow". The proceedings of this conference comprised the presentation and discussion of eight papers which surveyed the whole Canadian scene and assessed from a set of rather fundamental points of view the country's position in the world and the possible directions of its future development. The conference had been initiated by the Canadian Westinghouse Company, of Hamilton, Ontario, in celebration of the Company having attained its jubilee manufacturing in Canada, and the conference members, numbering more than three hundred, were the guests of the Company. Church, Government, education, administration, science and industry were represented. The papers and their authors were as follows : "The Canadian People", Dr. B. K. Sandwell, of the Financial Post; "Canada's Natural Resources", M. W. Mackenzie, executive vice-president, Canadian Chemical and Cellulose Co., Ltd. ; "The Challenge to Science", Dr. R. K. Stratford, scientific adviser, Imperial Oil, Ltd.; "The Contribution of Industry", D. W. Ambridge, president and general manager, Abitibi Power and Paper Co., Ltd.; "The Role of Government", M. Lamontagne, chairman of the Department of Economics, Laval University; "The Challenge to Education", Dr. N. A. M. Mackenzie, president of the University of British Columbia; "Cultural Evolution", Prof. H. Neatby, professor of history, University of Saskatchewan; "Canada in the World", Prof. D. G. Creighton, professor of history, University of Toronto; together with a paper representing a critical summary and assessment based on the papers just mentioned, which had been prepared by Prof. Denis Brogan, of the University of Cambridge, and which was presented at the dinner 